Florida International University FIU Digital Commons

FCE LTER Journal Articles

FCE LTER

2012

\title{
Controls on Ecosystem Carbon Dioxide Exchange in Short- and Long-Hydroperiod Florida Everglades Freshwater Marshes
}

Jessica L. Schedlbauer

Department of Biological Sciences, Florida International University and Department of Biology, West Chester University

Jay W. Munyon

Department of Biological Sciences, Florida International University

Steven F. Oberbauer

Department of Biological Sciences, Florida International University and Fairchild Tropical Botanic Garden

Evelyn E. Gaiser

Department of Biological Sciences, Florida International University, gaisere@fiu.edu

Gregory Starr

Department of Biological Sciences, University of Alabama

Follow this and additional works at: https://digitalcommons.fiu.edu/fce_lter_journal_articles

Part of the Ecology and Evolutionary Biology Commons, and the Environmental Sciences Commons

\section{Recommended Citation}

Publisher version: Schedlbauer, J., J. Munyon, S. Oberbauer, E.E. Gaiser, G. Starr. 2012. Controls on ecosystem carbon dioxide exchange in short- and long-hydroperiod Florida Everglades freshwater marshes. Wetlands 32: 801-812.

This material is based upon work supported by the National Science Foundation through the Florida Coastal Everglades Long-Term Ecological Research program under Cooperative Agreements \#DBI-0620409 and \#DEB-9910514. Any opinions, findings, conclusions, or recommendations expressed in the material are those of the author(s) and do not necessarily reflect the views of the National Science Foundation. This work is brought to you for free and open access by the FCE LTER at FIU Digital Commons. It has been accepted for inclusion in FCE LTER Journal Articles by an authorized administrator of FIU Digital Commons. For more information, please contact dcc@fiu.edu, jkrefft@fiu.edu. 
2 Controls on ecosystem carbon dioxide exchange in short- and long-hydroperiod Florida Everglades freshwater marshes

Jessica L. Schedlbauer ${ }^{1,2}$, Jay W. Munyon ${ }^{1}$, Steven F. Oberbauer ${ }^{1,3}$, Evelyn E. Gaiser ${ }^{1}$, Gregory Starr ${ }^{4}$

$8{ }^{1}$ Department of Biological Sciences 11200 SW $8^{\text {th }}$ St., Florida International University, $9 \quad$ Miami, FL 33199, USA

10 2Present address: Department of Biology, 750 S. Church St., West Chester University, West 11 Chester, PA 19383, USA

12 3Fairchild Tropical Botanic Garden, 10901 Old Cutler Rd., Coral Gables, FL 33156, USA

$13{ }^{4}$ Department of Biological Sciences, University of Alabama, Tuscaloosa, AL 35487, USA

14

15 Corresponding author: Jessica L. Schedlbauer, Department of Biology, 750 S. Church St., 16 West Chester University, West Chester, PA 19383, USA, Phone: 610-436-3175, Fax: 61017 436-2183, Email: jschedlbauer@wcupa.edu 


\section{Abstract}

2 Although freshwater wetlands are among the most productive ecosystems on Earth, little is

3 known of carbon dioxide $\left(\mathrm{CO}_{2}\right)$ exchange in low latitude wetlands. The Everglades is an

4 extensive, oligotrophic wetland in south Florida characterized by short- and long-

5 hydroperiod marshes. Chamber-based $\mathrm{CO}_{2}$ exchange measurements were made to

6 compare the marshes and examine the roles of primary producers, seasonality, and

7 environmental drivers in determining exchange rates. Low rates of $\mathrm{CO}_{2}$ exchange were

8 observed in both marshes with net ecosystem production reaching maxima of 3.77 and

$94.28 \mu \mathrm{mol} \mathrm{CO} \mathrm{m}^{-2} \mathrm{~s}^{-1}$ in short- and long-hydroperiod marshes, respectively. Fluxes of $\mathrm{CO}_{2}$

10 were affected by seasonality only in the short-hydroperiod marsh, where flux rates were

11 significantly lower in the wet season than in the dry season. Emergent macrophytes

12 dominated fluxes at both sites, though this was not the case for the short-hydroperiod

13 marsh in the wet season. Water depth, a factor partly under human control, significantly

14 affected gross ecosystem production at the short-hydroperiod marsh. As Everglades

15 ecosystem restoration proceeds, leading to deeper water and longer hydroperiods,

16 productivity in short-hydroperiod marshes will likely be more negatively affected than in

17 long-hydroperiod marshes. The Everglades stand in contrast to many freshwater wetlands

18 because of ecosystem-wide low productivity rates.

20 Keywords: carbon dioxide exchange; Everglades; productivity; water management;

21 wetland 


\section{Introduction}

2 Freshwater wetlands are unique ecosystems that provide important ecosystem services

3 including regulation of biogeochemical cycling, provision of habitat for distinctive species,

4 and flood control (Gopal et al. 2000; Zedler and Kercher 2005; Keddy et al. 2009). Globally,

5 wetlands are threatened by human activities such as residential and urban development, as

6 well as agricultural expansion (Dugan 1993; Dahl 2011). In the conterminous United

7 States, approximately half of all wetlands were lost by the 1970s (Mitsch and Gosselink

8 2007). As increased attention has focused on wetland conservation and research in recent

9 decades, carbon cycling and storage have emerged as areas of particular interest. Wetlands

10 are among the most productive ecosystems in the world, responsible for approximately

$116.3 \%$ of terrestrial net primary production (Houghton and Skole 1990; Neue et al. 1997;

12 Keddy 2000).

13 Most knowledge of wetland carbon dioxide $\left(\mathrm{CO}_{2}\right)$ exchange in non-agricultural,

14 freshwater systems is focused on mid- and high-latitude regions of the world (e.g. Bubier et

15 al. 1998; Hirota et al. 2006; Roulet et al. 2007; Rocha and Goulden 2008; Dusek et al. 2009).

16 Research over the course of the past decade has begun to explore $\mathrm{CO}_{2}$ exchange in the

17 tropics and sub-tropics (e.g. Morison et al. 2000; Jones and Humphries 2002; Jauhiainen et

18 al. 2005; Schedlbauer et al. 2010; Wright et al. 2011), but our knowledge of exchange rates

19 and their controls remains limited. There is much to be learned about carbon dynamics in

20 low latitude wetlands with year-round growing seasons and seasonality defined by wet and

21 dry periods.

22 The Everglades is a large $\left(>6,000 \mathrm{~km}^{2}\right)$ subtropical wetland located in south Florida

23 (Davis et al. 1994). The Everglades landscape has been subject to hydrologic management 
1 for more than a century, and water flows are regulated by canals, levees, and flow control

2 structures (USACE and SFWMD 1999). As a result of anthropogenic alterations, the

3 Everglades now occupies half of its former spatial extent (Light and Dineen 1994). In

4 addition, hydrologic modification has reduced water levels and hydroperiods (i.e., the

5 duration of inundation) relative to historical levels (Light and Dineen 1994). Current

6 construction proceeding under the Comprehensive Everglades Restoration Plan (CERP) is

7 intended, in part, to reverse these patterns. It is likely that plant community composition

8 and productivity will change in response to these alterations in the timing and quantity of

9 water delivery (Armentano et al. 2006; Childers et al. 2006a).

10 Short- and long-hydroperiod marshes are the two principal freshwater wetlands found

11 in the Everglades, and both are oligotrophic (Noe et al. 2001; Lodge 2005; Childers et al.

12 2006b). Short-hydroperiod marshes experience annual dry periods during which the

13 water table falls below the soil surface, while long-hydroperiod marshes are typically

14 inundated year-round. As such, the soils and communities of primary producers in these

15 marshes are quite different. Short-hydroperiod marshes are characterized by marl

16 (calcium carbonate) soils, and the plant community is dominated by a relatively uniform

17 grass-sedge canopy (Davis et al. 2005). In contrast, long-hydroperiod marshes have peat

18 soils and topography typified by sparsely vegetated sloughs and densely vegetated ridges

19 (Ogden 2005). Both types of marshes contain an additional group of primary producers,

20 periphyton, though biomass is much higher in short-hydroperiod marshes than in long-

21 hydroperiod marshes (Gottlieb et al. 2006).

22 Despite ecosystem oligotrophy, high rates of ecosystem productivity have been

23 reported in both short- and long-hydroperiod Everglades freshwater marshes (Ewe et al. 
1 2006). However, prior studies have not directly compared rates of $\mathrm{CO}_{2}$ exchange between

2 these contrasting ecosystems, nor have they evaluated the roles of primary producers and

3 climatic factors in driving rates of $\mathrm{CO}_{2}$ exchange. It is essential to understand these factors,

4 particularly in light of Everglades ecosystem restoration activities currently underway.

5 Three principal research questions were addressed in the present study: (1) How are net

6 ecosystem production (NEP), ecosystem respiration (ER), and gross ecosystem production

7 (GEP) affected by both seasonality and the experimental removal of a primary producer

8 group (i.e., macrophytes or periphyton) in short- and long-hydroperiod marshes? (2) How

9 do ecosystem $\mathrm{CO}_{2}$ exchange rates vary between short- and long-hydroperiod marshes? (3)

10 What environmental factors are the key drivers of NEP, ER, and GEP, and do these factors

11 vary between short- and long-hydroperiod marshes?

\section{Methods}

14 Study Sites

15 This research was conducted at two study sites (Fig. 1), a short-hydroperiod marsh

16 located within Taylor Slough at $25^{\circ} 26^{\prime} 16.50^{\prime \prime} \mathrm{N} 80^{\circ} 35^{\prime} 40.68^{\prime \prime} \mathrm{W}$ (a site hereafter referred to

17 as TS) and a long-hydroperiod marsh located within Shark River Slough at $25^{\circ} 33^{\prime} 6.72 \mathrm{~N}$

$1880^{\circ} 46^{\prime} 57.36^{\prime \prime} \mathrm{W}$ (a site hereafter referred to as SRS). Taylor and Shark River Sloughs are

19 the two major drainages of Everglades National Park, and the research described in the

20 present study was conducted prior to the initiation of any CERP-related restoration

21 activities. Mean annual temperature is $23.9^{\circ} \mathrm{C}$ and average rainfall is $143 \mathrm{~cm}$ per year

22 (NCDC 2009). Climate in south Florida is best characterized by wet and dry seasons (Beck

23 et al. 2006; Kottek et al. 2006) with the majority of the annual precipitation falling between 
1 May and October. Wet season precipitation is delivered via convectively formed clouds or

2 during the passage of tropical storms and hurricanes (Duever et al. 1994). Dry season

3 precipitation typically coincides with the passage of cold fronts over the Florida peninsula.

4 The TS site is a seasonally inundated freshwater marsh with a typical hydroperiod of

$5 \sim 5$ months per year (Schedlbauer et al. 2010). This site is characterized by shallow $(0.14$

$6 \mathrm{~m}$ ), marl soils, and the vegetation is dominated by sawgrass (Cladium jamaicense) and

7 muhly grass (Muhlenbergia capillaris). Vegetation is short-statured, reaching only $0.73 \mathrm{~m}$

8 above the soil surface. There is no seasonal variation in leaf area index $\left(1.8 \mathrm{~m}^{2} \mathrm{~m}^{-2}\right)$, or in

9 the aboveground biomass of one of the co-dominant plant species, C. jamaicense

10 (Schedlbauer et al. 2010). Periphyton is present at the site, and mats of periphyton begin

11 to grow substantially $\sim 2$ months into the wet season, forming dense "sweaters" around

12 submerged vegetation. When the site is dry, the periphyton exists as a desiccated mat,

13 often suspended in strands between individual plants and sometimes covering the soil

14 surface. Together, periphyton and submerged macrophytes contribute to the geochemical

15 fixation of $\mathrm{CO}_{2}$ as calcium carbonate during periods when the site is inundated. Seasonality

16 at TS is best defined by whether or not the site is inundated rather than climatic seasonality

17 because the two do not always coincide (Schedlbauer et al. 2010).

18 The SRS site is also a freshwater marsh, but is usually inundated year-round and is

19 characterized by ridge and slough topography (Ogden 2005). Soils are composed of peat

20 deposits that are $0.73 \mathrm{~m}$ deep within ridges and $0.66 \mathrm{~m}$ deep within sloughs. The

21 vegetation at SRS is different from that found at TS. C. jamaicense is dominant in ridge

22 areas, and a mixture of emergent spikerush (Eleocharis sp.), emergent panic grass

23 (Panicum sp.), and submerged bladderwort (Utricularia sp.) species dominate the sloughs. 
1 Vegetation height on ridges averages $1.34 \mathrm{~m}$ above the soil surface, while slough vegetation

2 is approximately $0.70 \mathrm{~m}$ above the soil. Periphyton is also present at SRS, floating at or

3 beneath the water surface, often in association with submerged vegetation. Seasonality at

4 this long-hydroperiod marsh is best defined by south Florida's climatic seasonality because

5 the site is typically inundated year-round. As such, there are slight mismatches in

6 seasonality between TS and SRS (Fig. 2A).

$7 \quad$ The TS and SRS sites are the locations of eddy covariance towers that are part of the

8 AmeriFlux network. At the towers, measurements of air temperature $\left(\mathrm{T}_{\text {air }}\right)$, relative

9 humidity (HMP45C, Vaisala, Helsinki, Finland), and photosynthetically active radiation

10 (PAR, PAR Lite, Kipp and Zonen, Delft, Netherlands) were made every $15 \mathrm{~s}$ and averaged at

1130 min intervals. Measurements were logged using both CR1000 and CR10X data loggers

12 (Campbell Scientific, Logan, UT). Measurements of water depth were made at both sites

13 with water level recorders installed in PVC wells (HOBO U20-001-01).

\section{Field Measurements}

15 Monthly chamber measurements of ecosystem $\mathrm{CO}_{2}$ exchange were made at both sites

16 for a period of approximately one year. Measurements of NEP and ER were made with

17 custom-made polycarbonate chambers. The chamber used at TS was $0.208 \mathrm{~m}^{3}(50.8 \mathrm{~cm} \times$

$1850.8 \mathrm{~cm} \times 80.6 \mathrm{~cm})$, while that used at SRS was $0.310 \mathrm{~m}^{3}(50.8 \mathrm{~cm} \times 50.8 \mathrm{~cm} \times 120.0 \mathrm{~cm})$.

19 Chamber height varied to accommodate differences in vegetation height at the two sites.

20 Each chamber was fitted with a 4+ m vent tube, a capped vent to aid in pressure

21 equilibration while seating the chamber, and an aluminum angle bar base covered with

22 closed-cell foam. Two box fans were affixed to the inside top of each chamber and were 
1 run constantly during measurement periods to ensure that air within the chambers was

2 well mixed. Chambers were configured for non-steady state, flow-through measurements.

3 During measurement periods, the chamber was coupled to a custom-made system to

4 measure chamber $\mathrm{CO}_{2}$ concentration. This system included a $\mathrm{LI}-840 \mathrm{CO}_{2} / \mathrm{H}_{2} \mathrm{O}$ infrared gas

5 analyzer (LI-COR, Inc., Lincoln, NE) coupled to a CR10X datalogger (Campbell Scientific,

6 Logan, UT) that recorded $\mathrm{CO}_{2}$ concentration every second. Air was drawn into the LI-840

7 with a pump (UNMP 105B, KNF Neuberger, Trenton, NJ) located downstream from the

8 analyzer. The flow rate was maintained at slightly $<1$ liter per minute with a rotameter

9 (VFA-22-SSV, Dwyer Instruments, Inc.) located upstream from the LI-840. Air was

10 circulated between the chamber and LI-840 through tubing (Bev-A-Line IV, Thermoplastic

11 Processes, Stirling, NJ). Measurements of PAR (LI-210, LI-COR, Inc., Lincoln, NE) were also

12 recorded by the datalogger at $1 \mathrm{~s}$ intervals during measurement periods.

13 When measurements were made, the chamber was placed over the measurement

14 location and checked to ensure that there was a leak-free seal at the base of the chamber.

15 After a 1 min equilibration period, a 1 min measurement period commenced.

16 Measurements of NEP were made under full-sun conditions and ER was measured with a

17 black nylon cloth placed over the chamber. Chamber measurements were typically made

18 between $10 \mathrm{AM}$ and $1 \mathrm{PM}$. The chamber was always vented between measurements to

19 ensure that $\mathrm{CO}_{2}$ concentration, $\mathrm{T}_{\text {air, }}$ and humidity remained as close to ambient conditions

20 as possible. When water was present at the study sites, water depth was measured at each

21 measurement location so that chamber volume could be adjusted accordingly.

22 The chamber measurement technique and experimental design varied between study

23 sites. In particular, different manipulative treatments were applied at each site to evaluate 
1 the roles of primary producers (i.e., macrophytes and periphyton) in determining $\mathrm{CO}_{2}$

2 exchange rates. At TS, a periphyton removal treatment was carried out in the dry season.

3 This treatment did not substantially disturb macrophytes and facilitated repeated

4 measurements over time (see below). However, at SRS the site was continually inundated

5 during measurement periods, and it was not possible to remove submerged periphyton

6 growing in close association with macrophytes. As a result, an above-water macrophyte

7 removal treatment was applied to plots that were first measured in an undisturbed state

8 (see below).

9 At TS, ten polyethylene bases $(50.8 \mathrm{~cm} \times 50.8 \mathrm{~cm} \times 15.2 \mathrm{~cm})$ were constructed and

10 seated in marl soil at the outset of the experiment. Bases were inserted an average of 3.8

$11 \mathrm{~cm}$ into the soil and were allowed to settle for at least two weeks prior to the start of the

12 experiment. Five bases served as controls and were not manipulated in any way. Five

13 additional bases were the treatment bases, subjected to the periphyton removal treatment.

14 During the dry season, periphyton was carefully removed from plants and the soil surface

15 by hand. Periphyton was removed only to the extent that it did not disturb the soil surface

16 or vegetation within each base. As such, a small amount of periphyton remained within

17 each of the treatment bases. No attempt was made to remove periphyton from within the

18 bases during periods of inundation or immediately after the water level dropped below the

19 soil surface. Periphyton grew in such close association with the vegetation and soil that

20 removal would have led to a high degree of disturbance.

21 During measurements at SRS, the site was constantly inundated with water, often

22 reaching $40+\mathrm{cm}$ above the soil surface (Fig. 2A). As a result, no bases were seated in the

23 soil. Instead, a float was constructed from a piece of foamboard and the chamber was 
1 placed over a $50.8 \mathrm{~cm} \times 50.8 \mathrm{~cm}$ hole in the board. This allowed the chamber to float above

2 the area of marsh that was to be measured. Chamber measurement plots were randomly

3 selected on each visit to the site and control (i.e., unmanipulated) measurements of NEP

4 and ER were made at each plot. Subsequent to these measurements, all emergent

5 macrophytes within the plot were clipped just beneath the water surface so that NEP and

6 ER could then be measured in treated plots. Clipped macrophytes were returned to the lab,

7 dried at $70^{\circ} \mathrm{C}$ for 48 hours, and weighed.

8 Chamber measurements were made regularly at TS over the period from April 2008

9 through August 2009. Measurements at SRS began later and occurred on fewer dates

10 because of limited site access during periods with low water levels. The SRS site is remote

11 and chamber measurements could be made only when the site was accessible by airboat.

\section{Data Processing and Statistical Analyses}

13 Measurements of $\mathrm{CO}_{2}$ concentration within the chamber during a measurement period

14 were plotted as a function of time, and linear regression was used to determine the rate of

15 change in $\mathrm{CO}_{2}$ concentration over each 1 min measurement period (i.e., the slope of the

16 relationship). These data were then used to determine $\mathrm{CO}_{2}$ flux rates in $\mu \mathrm{mol} \mathrm{m} \mathrm{m}^{-2} \mathrm{~s}^{-1}$ as,

$17 \quad \mathrm{CO}_{2}$ flux $=(\mathrm{dC} / \mathrm{dt}) \times\left(\left(\mathrm{p}_{\mathrm{a}} \mathrm{V}\right) /(\mathrm{T}\right.$ R A $\left.)\right)$

18 where $\mathrm{dC} / \mathrm{dt}$ is the slope described above, $\mathrm{p}_{\mathrm{a}}$ is atmospheric pressure $(\mathrm{Pa}), \mathrm{V}$ is chamber

19 volume $\left(\mathrm{m}^{3}\right), \mathrm{T}$ is temperature $(\mathrm{K}), \mathrm{R}$ is the gas constant $\left(8.3143 \mathrm{~J} \mathrm{~mol}^{-1} \mathrm{~K}^{-1}\right)$, and $\mathrm{A}$ is

20 chamber area $\left(\mathrm{m}^{2}\right)$. Chamber volume was allowed to vary with water level at each

21 measurement location.

22 Individual measurements of NEP and ER at each base or plot location were used to 23 determine gross ecosystem production (GEP) as, 
$1 \quad$ GEP $=$ NEP - ER

2 where positive values indicate $\mathrm{CO}_{2}$ uptake by the ecosystem and negative values indicate

$3 \mathrm{CO}_{2}$ release from the ecosystem.

$4 \quad$ The statistical analyses described below were performed with $\mathrm{R}$ (version 2.13.0, The R

5 Foundation for Statistical Computing, 2011). The effects of the experimental treatments

6 and seasonality on NEP, ER, and GEP at both sites were examined with linear mixed-effects

7 models (Schabenberger and Pierce 2002). The fixed effects at both sites were treatment

8 (at TS: periphyton removal and control, at SRS: macrophyte removal and control), season

9 (wet and dry), and the treatment by season interaction term. The random effect at both

10 sites was measurement location (at TS: base location, at SRS: measurement plot). At TS,

11 periphyton removal treatment measurements were eliminated from the dataset for all

12 dates more than two months into the wet season. As described above, it was not possible

13 to remove periphyton from within the bases after this time. Therefore, the analysis of the

14 experimental treatment at TS was only for the mid to late dry season and early wet season.

15 The mixed-effects statistical design accommodated an unbalanced study design. In

16 addition to the late-wet season and early dry season data that were eliminated at TS, the

17 weather occasionally made it impossible to complete a full set of chamber measurements.

18 Analysis of variance (ANOVA) was used to examine whether NEP, ER, and GEP varied

19 between the short- and long-hydroperiod marshes. Specifically, dry and wet season data

20 from the control treatments at TS were compared with seasonally-pooled control

21 treatment data from SRS. Data were analyzed in this manner because of the findings from

22 the mixed effects model analysis, as discussed below. To meet the ANOVA assumptions of

23 normality and equal variances, it was necessary to apply a square root transformation to 
1 the GEP data in the TS wet season vs. SRS comparison and to remove three outliers

2 (residuals $>2$ standard deviations from the mean) from the ER TS dry season vs. SRS

3 comparison.

4 Multiple linear regressions were used to determine the effect of various environmental

5 factors on rates of $\mathrm{CO}_{2}$ exchange at each study site. Regressions were performed on control

6 treatment NEP, ER, and GEP values expressed as means for each measurement date.

7 Forward and backward stepwise multiple regressions were performed using the Akaike

8 Information Criterion (AIC) to select predictor variables for the final models (R Package

9 MASS, stepAIC function). Full models for NEP and GEP included water depth relative to the

10 soil surface, $T_{\text {air }}$, vapor pressure deficit (D, as the vapor pressure difference between

11 saturated and ambient air at $\mathrm{T}_{\text {air }}$, and PAR as predictor variables. In the ER analysis, PAR

12 was not used as a predictor variable because measurements were made in the dark.

13 Potential predictor variables such as soil temperature, water temperature, and soil

14 volumetric water content were excluded from the analysis because of multicollinearity

15 with the selected variables. Most environmental data used in the models were drawn from

16 the half-hourly micrometeorological dataset and were averaged across the time period

17 during which chamber measurements were made (i.e., from $10 \mathrm{AM}$ to $1 \mathrm{PM}$ ). The one

18 exception was the PAR data, which was calculated as a mean of the PAR measurements

19 made during each 1 min chamber measurement period.

\section{Results}

22 Micrometeorological site comparison 
Water levels varied seasonally at both TS and SRS with the highest water levels in the wet season and the lowest levels in the dry season (Fig. 2A). Climatically-defined

3 seasonality did not coincide well with site-specific seasonality at TS in 2008, though it

4 matched well in 2009 (Fig. 2A). Measurements of $\mathrm{T}_{\text {air }}$, D, and maximum daily PAR (PAR $\max _{\text {) }}$

5 were similar between study sites and exhibited expected seasonal patterns (Fig. 2B, C, D). Treatment and seasonal effects on NEP, ER, and GEP

$7 \quad$ At the short-hydroperiod TS marsh, the periphyton removal treatment had no 8 significant effect on NEP, ER, or GEP ( $p>0.05$, Table 1, Fig. 3). It should be noted that this 9 treatment was effectually applied only during the mid to late dry season and early wet 10 season. Seasonality did have an effect on all three parameters, with significantly higher 11 rates of NEP, ER, and GEP observed in the dry season ( $\mathrm{p}<0.001$, Table 1, Fig. 3). For all

12 analyses at TS, the treatment by season interaction was not significant $(\mathrm{p}>0.05)$.

13 At the long-hydroperiod SRS marsh, the macrophyte removal treatment had a 14 significant effect on both NEP and GEP ( $p<0.0001)$, but not on ER ( $p>0.05$, Table 1$)$.

15 Significantly higher rates of NEP and GEP were observed for measurements made prior to 16 macrophyte removal (Fig. 4). In contrast to TS, there was no significant effect of

17 seasonality on any of the $\mathrm{CO}_{2}$ exchange parameters at SRS. As such, all data from SRS were 18 pooled across seasons for subsequent analyses. The treatment by season interaction was

19 not significant for any of these analyses at SRS ( $p>0.05$, Table 1, Fig. 4).

20 Short- vs. long-hydroperiod comparisons of $\mathrm{CO}_{2}$ exchange

21 Net ecosystem production did not differ significantly between TS in the dry season and

22 SRS ( $p>0.05)$, though ER and GEP did differ significantly $(p<0.001$, Table 2). Both ER and

23 GEP were significantly greater at TS during the dry season than they were at SRS. These 
1 relationships changed when the TS wet season data were compared to the seasonally-

2 pooled data from SRS. In this case, NEP, ER, and GEP were all significantly different $(\mathrm{p}<$

3 0.001) between sites with NEP and GEP greater at SRS, while ER remained greater at TS

4 (Table 2).

$5 \quad$ Environmental drivers of NEP, ER, and GEP

6 Multiple regression analyses indicated that $\mathrm{T}_{\text {air }}$ and $\mathrm{D}$ best predicted rates of NEP at TS, 7 while at SRS, $\mathrm{T}_{\text {air }}$ and PAR were the most important predictor variables for NEP. However,

8 neither of these regression equations accounted for much of the variation in the data $\left(\mathrm{R}^{2}\right.$ adj

9 of 0.26 and 0.24 for TS and SRS, respectively) and neither equation was significant ( $p>$

100.05 , Table 3). The regression equations used to predict ER were significant at both sites (p

$11<0.05$ ) and included the variables water depth and D at TS and $\mathrm{T}_{\text {air }}$ and $\mathrm{D}$ at SRS (Table 3).

12 These equations explained $62 \%$ of the variation in ER rates at TS and 59\% at SRS.

13 Equations for GEP were also significant at both sites $(\mathrm{p}<0.05)$ and included water depth,

$14 \mathrm{~T}_{\text {air }}$, and $\mathrm{D}$ at TS, but only $\mathrm{T}_{\text {air }}$ at SRS (Table 3). The explanatory power of the GEP equation

15 was higher at TS than at SRS ( $\mathrm{R}^{2}$ adj of 0.65 and 0.34 , respectively).

16 Although PAR is an important driver of $\mathrm{CO}_{2}$ exchange, it was only incorporated as a

17 variable in the multiple regression analyses to account for seasonal variation (Fig. 2b).

18 Measurements of NEP were made under full-sun conditions and were assumed to

19 represent maximum daily rates of NEP. An analysis of PAR recorded during the 1 minute

20 NEP measurement intervals revealed that on all but two days (at SRS on 10/30/08 and

$217 / 17 / 09$ ) PAR was greater than or equal to (i.e., within one standard error) mean PAR

22 values recorded by the nearby micrometeorological stations during the measurement

23 period (data not shown). 
1 In addition to environmental drivers, it was possible to explore the relationship

2 between plant biomass and $\mathrm{CO}_{2}$ exchange at SRS because of the nature of the macrophyte

3 removal treatment. Linear regression analyses indicated that plant dry biomass exhibited

4 a significant positive relationship with both NEP and GEP at SRS $\left(\mathrm{R}^{2}\right.$ adj $=0.71$ and 0.58 ,

5 respectively, $\mathrm{p}<0.0001$, data not shown). There was no significant relationship between

$6 \quad$ ER and plant biomass ( $p>0.05$, data not shown).

8 Discussion

9 Treatment and seasonal effects on NEP, ER, and GEP

10 Contrasting patterns of $\mathrm{CO}_{2}$ flux responses to experimental treatments and seasons

11 were observed between the short- and long-hydroperiod Everglades marshes. At the

12 short-hydroperiod TS marsh, no significant differences in $\mathrm{CO}_{2}$ exchange rates were

13 observed in the control vs. periphyton removal treatments. This indicated that during the

14 period in which the treatment was effectively applied (i.e., the mid-dry to early wet

15 season), periphyton did not significantly contribute to $\mathrm{CO}_{2}$ fluxes at the site. Although

16 periphyton exhibits an immediate metabolic response to rewetting in the wet season

17 (Thomas et al. 2006a), the contribution of periphyton to ecosystem $\mathrm{CO}_{2}$ exchange was not

18 strong enough to be detected.

19 Seasonality played a key role in influencing rates of $\mathrm{CO}_{2}$ exchange at TS, such that

20 exchange rates were significantly lower during periods of inundation. The seasonal

21 patterns of NEP, ER, and GEP mirrored those reported at the nearby eddy covariance tower

22 (Schedlbauer et al. 2010). Flux rates were highest in the dry season, declined through the

23 early part of the wet season, and then increased again as the wet season proceeded. 
1 Similarity between the two measurement methods was reflected in a linear regression

2 analysis of mean control chamber derived NEP vs. eddy covariance derived NEP (mean

3 values from $10 \mathrm{AM}$ to $1 \mathrm{PM}$ on the chamber measurement dates). This analysis yielded a

4 significant, positive relationship between the two methods $\left(y=1.10 x-0.58, R^{2}\right.$ adj $=0.70, p$

$5<0.001$, data not shown). Chamber measurements indicated that dry season fluxes were

6 clearly dominated by contributions from macrophytes, though heterotrophic contributions

7 from the well-aerated soil also played a role in determining ER. In the daytime hours of the

8 dry season, the TS marsh was a net sink for $\mathrm{CO}_{2}$, and maximum rates of NEP reached 3.77

$9 \mu \mathrm{mol} \mathrm{CO} \mathrm{m}^{-2} \mathrm{~s}^{-1}$.

10 Following the onset of the wet season, the TS ecosystem became a net source of $\mathrm{CO}_{2}$ to

11 the atmosphere during the daytime with NEP rates reaching a minimum of $-1.36 \mu \mathrm{mol} \mathrm{CO}_{2}$

$12 \mathrm{~m}^{-2} \mathrm{~s}^{-1}$. The wet season shift from $\mathrm{CO}_{2}$ sink to source principally reflected the seasonal

13 suppression of photosynthesis by macrophytes following flooding of the site (Schedlbauer

14 et al. 2010). The subsequent transition from low to moderate flux rates during the wet

15 season can be attributed to the growth and development of dense periphyton mats $\sim 2$

16 months into the season (Thomas et al. 2006b; Schedlbauer et al. 2010). It appears that

17 large, metabolically active periphyton mats shifted the ecosystem from net $\mathrm{CO}_{2}$ source to

18 sink as the wet season proceeded. The contribution of periphyton to primary production at

19 TS was principally confined to the mid to late wet season. Although a prior study indicated

20 that periphyton was responsible for $>50 \%$ of aboveground net primary production (ANPP)

21 at TS (Ewe et al. 2006), the present data set suggests a smaller role for periphyton in

22 determining site productivity. Scaling errors in the previous study may have contributed to

23 this discrepancy (Schedlbauer et al. 2010). The depressed NEP rates in the wet season also 
1 indicate that geochemical fixation of $\mathrm{CO}_{2}$ and subsequent marl accretion at TS was

2 proceeding slowly.

3 In contrast to TS, treatment effects were strong and seasonal effects were non-existent

4 at the long-hydroperiod SRS marsh. Rates of $\mathrm{CO}_{2}$ exchange were strongly driven by

5 contributions from the emergent macrophyte community. In the absence of emergent

6 macrophytes, NEP, ER, and GEP rates significantly decreased and were often close to zero.

7 The effect of macrophyte removal was most dramatic for NEP and GEP, given that rates of

8 ER were low year-round, regardless of treatment. These data indicate that the contribution

9 of periphyton to ecosystem $\mathrm{CO}_{2}$ exchange was minor in this long-hydroperiod marsh. This

10 finding supports data reported by Ewe et al. (2006) indicating that periphyton contributes

11 only $10 \%$ of the average ANPP at this study site.

12 As a peat marsh, it was expected that the long-hydroperiod SRS ecosystem would act as

$13 \mathrm{a} \mathrm{CO}_{2}$ sink and, on each measurement date under mid-day, full sun conditions, this was

14 found to be the case. Rates of NEP varied from 1.36 to $4.28 \mu \mathrm{mol} \mathrm{CO}_{2} \mathrm{~m}^{-2} \mathrm{~s}^{-1}$. Despite data

15 showing the site as a $\mathrm{CO}_{2}$ sink during daytime hours, the unusually dry conditions recorded

16 at the site in spring 2009 exposed peat soil at the site (J.L. Schedlbauer, personal

17 observation), and the exposure of these carbon-rich soils likely switched the site from $\mathrm{CO}_{2}$

18 sink to source. Unfortunately, chamber measurements were logistically impossible during

19 this time period. The historical occurrence of site dry-downs is unknown, but likely to be

20 rare given the presence of $>0.65 \mathrm{~m}$ deep peat deposits at the site.

21 In comparison with other subtropical and tropical freshwater wetlands where $\mathrm{CO}_{2}$

22 exchange rates have been measured, the findings reported for these Everglades marshes

23 are notably different. Typically, net rates of $\mathrm{CO}_{2}$ uptake by tropical wetlands are highest in 
1 the wet season and lowest in the dry season (Morison et al. 2000; Jones and Humphries

2 2002). This pattern was not found in either short- or long-hydroperiod Everglades

3 marshes; the pattern was opposite at TS and there was no pattern at SRS. The seasonal

4 stimulation of primary productivity in many low-latitude wetlands is absent in these

5 oligotrophic Everglades marshes.

6 Short-vs. long-hydroperiod comparisons of $\mathrm{CO}_{2}$ exchange

$7 \quad$ Both TS and SRS exhibited statistically similar rates of NEP when compared during the

8 TS dry season. This was unexpected given the contrasting primary producer communities

9 and hydroperiods at these sites. However, both GEP and ER were significantly higher at TS,

10 likely reflecting the contributions of the well-aerated soil microbial community to $\mathrm{CO}_{2}$

11 fluxes from the site. During the wet season at TS, macrophyte leaf area was submerged and

12 photosynthetic rates declined (Schedlbauer et al. 2010), and this led to rates of NEP and

13 GEP that were significantly lower than at SRS. Despite the fact that both sites share $C$.

14 jamaicense as a dominant plant species, inundation had contrasting effects on site

15 productivity. These data suggest that the $C$. jamaicense population at SRS is better adapted

16 to flooded conditions, an idea supported by ANPP data for the species. C. jamaicense ANPP

17 at SRS is nearly double the value reported for TS (606 vs. $304 \mathrm{~g} \mathrm{C} \mathrm{m}^{-2}$ year-1, Ewe et al.

18 2006).

19 The seasonal and year-round mean values for NEP, ER, and GEP compared favorably

20 with data collected at the eddy covariance towers at each site (Schedlbauer et al. 2010; K.L.

21 Jimenez, unpublished manuscript). Carbon dioxide fluxes determined using chamber

22 measurement methods clearly captured representative data at both sites. However, it

23 should be noted that measurements of ER during inundated periods at both study sites may 
1 have underestimated true ER. Although the chamber was darkened for $\sim 1$ min before a

2 measurement was recorded, it is probable that lags were present in the system. In sunlight,

3 aquatic photosynthesis will decrease the dissolved $\mathrm{CO}_{2}$ concentration in the water column

4 and cause a net flux of $\mathrm{CO}_{2}$ into the water. This flux likely continued following chamber

5 darkening because equilibration of $\mathrm{CO}_{2}$ in a large volume of water proceeds relatively

6 slowly. Further, because the chamber was placed on a float at SRS, it is possible that water

7 upstream from the darkened chamber flowed under the float during ER measurements.

8 Although water flow at SRS is slow $\left(1.5-4.5 \mathrm{~cm} \mathrm{~s}^{-1}\right.$, Riscassi and Schaffranek 2002), the

9 introduction of recently sunlit water depleted in dissolved $\mathrm{CO}_{2}$ may have affected ER

10 measurements. Because of these possibilities, ER may have been underestimated at TS in

11 the wet season and at SRS year-round.

12 The data collected from these Everglades marshes contrast with other studies of $\mathrm{CO}_{2}$

13 exchange in wetlands at low latitudes. Carbon dioxide flux rates in both short- and long-

14 hydroperiod marshes were much lower than values reported elsewhere. For instance, the

15 maximum rates of net $\mathrm{CO}_{2}$ uptake in a papyrus (Cyperus papyrus) wetland were reported to

16 reach $24 \mu \mathrm{mol} \mathrm{CO} \mathrm{m}^{-2} \mathrm{~s}^{-1}$ (Jones and Humphries 2002), while maximum values in an

17 Amazonian floodplain were $>40 \mu \mathrm{mol} \mathrm{CO} \mathrm{m}^{-2} \mathrm{~s}^{-1}$ (Morison et al. 2000). Also, in

18 comparison with growing season data from freshwater wetlands at mid to high latitude,

19 these Everglades $\mathrm{CO}_{2}$ exchange rates were low (Bonneville et al. 2008; Rocha and Goulden

20 2008; Dusek et al. 2009). The present data strongly reflect the oligotrophic nature of

21 Everglades wetlands, where phosphorous availability is known to limit the productivity of

22 periphyton and macrophytes including C. jamaicense and Eleocharis sp. (Daoust and

23 Childers 1999; Noe et al. 2001; Iwaniec et al. 2006). 


\section{Environmental drivers of NEP, ER, and GEP}

2 Environmental drivers of $\mathrm{CO}_{2}$ exchange varied between the short- and long-

3 hydroperiod study sites. Considering the significant multiple regression equations for ER

4 and GEP, the most notable finding is that water level influenced both terms at TS, but had

5 no effect at SRS. This supports the findings reported above showing a significant seasonal

6 effect on $\mathrm{CO}_{2}$ exchange at TS, but not at SRS. This relationship is important in light of

7 impending changes in Everglades water management as the Comprehensive Everglades

8 Restoration Plan (CERP) proceeds. These data indicate that increased water depths and

9 longer hydroperiods will have a substantial effect on $\mathrm{CO}_{2}$ exchange in short-hydroperiod

10 marshes, but a limited effect within long-hydroperiod marshes. While other environmental

11 drivers (i.e., $T_{\text {air }}, \mathrm{D}, \mathrm{PAR}$ ) influence NEP, ER, and GEP, these factors are largely beyond

12 human control.

13 The weakness of the relationship between environmental drivers and the NEP and GEP

14 terms at SRS was likely related to heterogeneity in the site's plant community. Both terms

15 were significantly related to plant biomass, a metric that varies substantially from ridge to

16 slough. It seems that variation in the amount of plant material enclosed by the

17 measurement chamber was more important than any environmental variable in

18 determining $\mathrm{CO}_{2}$ exchange rates. However, the same cannot be said for the weak

19 relationship between environmental drivers and NEP at TS where vegetation is relatively

20 heterogeneous. A longer-term dataset may help to resolve the role of environmental

21 drivers in determining NEP.

22 Conclusions 
Although wetlands are among the world's most productive ecosystems, the freshwater

2 marshes of the Everglades are atypical. In contrast to previous research (Ewe et al. 2006),

3 the data reported here reflect that the Everglades is an oligotrophic ecosystem with low

4 productivity in both short- and long-hydroperiod marshes. Everglades wetlands are also

5 distinguished because seasonal cues, specifically the transition from dry to wet season, do

6 not yield pulses in productivity, as reported in other low-latitude wetland ecosystems.

$7 \quad$ Despite contrasting plant communities, net ecosystem production was surprisingly

8 similar between short-hydroperiod marshes in the dry season and long-hydroperiod

9 marshes year-round. Further, it is clear that (emergent) macrophytes were the dominant

10 contributors to $\mathrm{CO}_{2}$ exchange rates during these periods. Whether these similarities will

11 persist in the future, as Everglades restoration under CERP proceeds, is uncertain.

12 It is likely that productivity in short-hydroperiod marshes, rather than long-

13 hydroperiod marshes, will be most affected by alterations in the timing and quantity of

14 water delivery to the Everglades. The current study shows that rates of $\mathrm{CO}_{2}$ exchange in

15 short-hydroperiod marshes like TS are highly sensitive to seasonality and water levels.

16 Deeper water and longer hydroperiods are likely to decrease the amount of carbon stored

17 by these ecosystems on an annual basis. Additionally, past research indicates that plant

18 communities in short-hydroperiod Everglades marshes can change rapidly (i.e., within 3-4

19 years) in response to altered hydrologic regimes (Armentano et al. 2006). As a result, these

20 ecosystems may shift toward more hydrophytic plant communities. The net effect of

21 Everglades restoration activities on productivity in short-hydroperiod marshes is, as yet,

22 unclear, but any alterations will have wide-ranging effects given that these marshes occupy

23 approximately one-third of the Everglades' spatial extent (Davis et al. 2005). 


\section{Acknowledgements}

3 This research was funded by the Department of Energy's National Institute for Climate

4 Change Research through grant number 07-SC-NICCR-1059. Thanks to Paulo Olivas and

5 Jose Luciani for assistance in the field. Thanks also to Everglades National Park (Permits

6 EVER-2007-SCI-0065, EVER-2008-SCI-0015 and EVER-2009-SCI-0013) and the Florida

7 Coastal Everglades LTER project. The authors are grateful for the useful comments

8 provided by three anonymous reviewers.

\section{References}

11 Armentano TV, Sah JP, Ross MS, Jones DT, Cooley HC, Smith CS (2006) Rapid responses of

12 vegetation to hydrological changes in Taylor Slough, Everglades National Park, Florida,

13 USA. Hydrobiologia 569:293-309

14 Beck C, Grieser M, Kottek M, Rubel F, Rudolf B (2006) Characterizing global climate change

15 by means of Köppen Climate Classification. Klimastatusbericht 2005:139-149

16 Bonneville M-C, Strachan IB, Humphreys ER, Roulet NT (2008) Net ecosystem $\mathrm{CO}_{2}$

17 exchange in a temperate cattail marsh in relation to biophysical properties. Agricultural

18 and Forest Meteorology 148:69-81

19 Bubier JL, Crill PM, Moore TR, Savage K, Varner RK (1998) Seasonal patterns and controls

20 on net ecosystem $\mathrm{CO}_{2}$ exchange in a boreal peatland complex. Global Biogeochemical

$21 \quad$ Cycles 12:703-714

22 Childers DL, Iwaniec D, Rondeau D, Rubio G, Verdon E, Madden CJ (2006a) Responses of

23 sawgrass and spikerush to variation in hydrologic drivers and salinity in Southern 
Everglades marshes. Hydrobiologia 596:273-292

2 Childers DL, Boyer JN, Davis SE, Madden CJ, Rudnick DT, Sklar FH (2006b) Relating

3 precipitation and water management to nutrient concentrations in the oligotrophic

4 "upside-down" estuaries of the Florida Everglades. Limnology and Oceanography 51:

$5 \quad 602-616$

6

7

8

9

10

11

12

13 Davis SM, Gaiser EE, Loftus WF, Huffman AE (2005) Southern marl prairies conceptual

14 ecological model. Wetlands 25:821-831

15 Daoust RJ, Childers DL (1999) Controls on emergent macrophyte composition, abundance,

16 and productivity in freshwater Everglades wetland communities. Wetlands 19:262-275

17 Duever MJ, Meeder JF, Meeder LC, McCollom JM (1994) The climate of south Florida and its

18 role in shaping the Everglades ecosystem. In: Davis SM, Ogden JC (eds) Everglades: the

19 Ecosystem and its Restoration. St. Lucie Press, Delray Beach, pp 225-248

20 Dugan P (ed) (1993) Wetlands: a World Conservation Atlas. Oxford University Press, New

$21 \quad$ York, $187 \mathrm{pp}$

22 Dusek J, Cizkova H, Czerny R, Taufarova K, Smidova M, Janous D (2009) Influence of

23 summer flood on the net ecosystem exchange of $\mathrm{CO}_{2}$ in a temperate sedge-grass marsh. 
Agricultural and Forest Meteorology 149:1524-1530

2 Ewe SML, Gaiser EE, Childers DL, Iwaniec D, Rivera-Monroy VH, Twilley RR (2006) Spatial

3 and temporal patterns of aboveground net primary productivity (ANPP) along two

4 freshwater-estuarine transects in the Florida Coastal Everglades. Hydrobiologia

$5 \quad 569: 459-474$

6 Gopal B, Junk WJ, Davis JS (eds) (2000) Biodiversity in Wetlands: Assessment, Function,

$7 \quad$ and Conservation. Backhuys Publishers, Leiden, 353 pp

8 Gottlieb AD, Richards JH, Gaiser EE (2006) Comparative study of periphyton community

9 structure in long and short-hydroperiod Everglades marshes. Hydrobiologia 569:195-

$10 \quad 207$

11 Hirota M, Tang Y, Hu Q, Hirata S, Kato T, Mo W, Cao G, Mariko S (2006) Carbon dioxide

12 dynamics and controls in a deep-water wetland on the Qinghai-Tibetan Plateau.

$13 \quad$ Ecosystems 9:673-688

14 Houghton RA, Skole DL (1990) Carbon. In: Turner BL, Clark WC, Kates RW, Richards JF,

15 Mathews JT, Meyer WB (eds) The Earth as Transformed by Human Action. Cambridge

16 University Press, New York, pp 393-408

17 Iwaniec DM, Childers DL, Rondeau D, Madden CJ, Saunders C (2006) Effects of hydrologic

18 and water quality drivers on periphyton dynamics in the southern Everglades.

19 Hydrobiologia 569:223-235

20 Jauhiainen J, Takahashi H, Heikkienen JEP, Martikainen PJ, Vasander H (2005) Carbon

21 fluxes from a tropical peat swamp forest floor. Global Change Biology 11:1788-1797

22 Jones MB, Humphries SW (2002) Impacts of the $\mathrm{C}_{4}$ sedge Cyperus papyrus L. on carbon and

23 water fluxes in an African wetland. Hydrobiologia 488:107-113 
1 Keddy PA (2000) Wetland Ecology Principles and Conservation. Cambridge University

2 Press, New York, $614 \mathrm{pp}$

3 Keddy PA, Fraser, LH, Solomesch AI, Junk WJ, Campbell DR, Arroyo MTK, Alho CJR (2009)

$4 \quad$ Wet and wonderful: the world's largest wetlands are conservation priorities. BioScience $5 \quad 59: 39-51$

6 Kottek M, Grieser J, Beck C, Rudolf B, Rubel F (2006) World map of the Köppen-Geiger

7 climate classification updated. Meteorologische Zeitschrift 15:259-263

8 Light SS, Dineen JW, (1994) Water control in the Everglades: a historical perspective. In:

9 Davis SM, Ogden JC (eds) Everglades: the Ecosystem and its Restoration. St. Lucie Press,

10 Delray Beach, pp 47-84

11 Lodge TE (2005) The Everglades Handbook: Understanding the Ecosystem. CRC Press, New 12 York, $302 \mathrm{pp}$

13 Mitsch WJ, Gosselink JG (2007) Wetlands. John Wiley and Sons, Inc., Hoboken, 582 pp

14 Morison JIL, Piedade MTF, Müller E, Long SP, Junk WJ, Jones MB (2000) Very high

15 productivity of the $\mathrm{C}_{4}$ aquatic grass Echinochloa polystachya in the Amazon floodplain

16 confirmed by net ecosystem $\mathrm{CO}_{2}$ flux measurements. Oecologia 125:400-411

17 National Climatic Data Center (NCDC) (2009) Royal Palm Rs daily surface data.

18 http://www.ncdc.noaa.gov/oa/ncdc.html, NCDC, Asheville, accessed 4/10/09

19 Neue HU, Gaunt JL, Wang ZP, Becker-Heidmann P, Quijano C (1997) Carbon in tropical

20 wetlands. Geoderma 79:163-185

21 Noe GB, Childers DL, Jones RD (2001) Phosphorus biogeochemistry and the impact of

22 phosphorus enrichment: why is the Everglades so unique? Ecosystems 4:603-624

23 Ogden JC (2005) Everglades ridge and slough conceptual ecological model. Wetlands 
2 Riscassi AL, Schaffranek RW (2002) Flow velocity, water temperature, and conductivity in

3 Shark River Slough, Everglades National Park, Florida: July 1999 - August 2001. U.S.

$4 \quad$ Geological Survey, Reston, $40 \mathrm{pp}$

5 Rocha AV, Goulden ML (2008) Large interannual $\mathrm{CO}_{2}$ and energy exchange variability in a

6 freshwater marsh under consistent environmental conditions. Journal of Geophysical

$7 \quad$ Research 113:G04019

8 Roulet NT, LaFleur PM, Richard PJH, Moore TR, Humphreys ER, Bubier J (2007)

9 Contemporary carbon balance and late Holocene carbon accumulation in a northern

10 peatland. Global Change Biology 13:397-411

11 Schabenberger 0, Pierce FJ (2002) Contemporary Statistical Models for the Plant and Soil

12 Sciences. CRC Press, New York, 738 pp

13 Schedlbauer JL, Oberbauer SF, Starr G, Jimenez KL (2010) Seasonal differences in the $\mathrm{CO}_{2}$

14 exchange of a short-hydroperiod Florida Everglades marsh. Agricultural and Forest

$15 \quad$ Meteorology 150:994-1006.

16 Thomas S, Gaiser EE, Gantar M, Scinto LJ (2006a) Quantifying the responses of calcareous

17 periphyton crusts to rehydration: a microcosm study (Florida Everglades). Aquatic

$18 \quad$ Botany $84: 317-323$

19 Thomas S, Gaiser EE, Tobias FA (2006b) Effects of shading on calcareous benthic

20 periphyton in a short-hydroperiod oligotrophic wetland (Everglades, FL, USA).

$21 \quad$ Hydrobiologia 569:209-221

22 U.S. Army Corps of Engineers (USACE) and South Florida Water Management District

23 (SFWMD) (1999) Central and Southern Florida Project Comprehensive Review Study, 
1 Final Integrated Feasibility Report and Programmatic Environmental Impact Statement.

2 USACE, Jacksonville District, Jacksonville and SFWMD, West Palm Beach, 4033 pp

3 Wright EL, Black CR, Cheesman AW, Drages T, Large D, Turner BL, Sjögersten S (2011)

4 Contribution of subsurface peat to $\mathrm{CO}_{2}$ and $\mathrm{CH}_{4}$ fluxes in a neotropical peatland. Global

$5 \quad$ Change Biology 17:2867-2881

6 Zedler JB, Kercher S (2005) Wetland resources: status, trends, ecosystem services, and

7 restorability. Annual Review of Environment and Resources 30:39-74 
1 Table 1. F-values from mixed-effects ANOVA analyses of net ecosystem production (NEP),

2 ecosystem respiration (ER), and gross ecosystem production (GEP) measured at Taylor

3 Slough (TS) and Shark River Slough (SRS). All models had the fixed effects treatment,

4 season, and treatment by season interaction. Treatment at TS was the periphyton removal,

5 while at SRS it was the macrophyte removal, and both treatments were compared with

6 control measurements. Season refers to dry or wet season. Asterisks indicate significance

7 at the following levels: $\mathrm{p}<0.001\left({ }^{* *}\right), 0.001 \leq \mathrm{p} \leq 0.01\left(^{* *}\right), 0.01<\mathrm{p} \leq 0.05\left(^{*}\right)$.

8

\begin{tabular}{ccccc} 
Site & Variable & Treatment & Season & $\begin{array}{c}\text { Treatment } \times \\
\text { Season }\end{array}$ \\
\hline \multirow{3}{*}{ TS } & NEP & 0.04 & $27.74 * * *$ & 0.41 \\
& ER & 0.59 & $65.13^{* * *}$ & 0.08 \\
& GEP & 0.21 & $109.12^{* * *}$ & 0.88 \\
SRS & NEP & $132.44^{* * *}$ & 2.79 & 2.88 \\
& ER & $11.45^{* *}$ & 0.14 & 3.52 \\
& GEP & $117.98^{* * *}$ & 2.91 & 3.82
\end{tabular}

10 
1 Table 2. Mean \pm one SE for $\mathrm{CO}_{2}$ exchange rates $\left(\mu \mathrm{mol} \mathrm{CO} \mathrm{Cm}^{-2} \mathrm{~s}^{-1}\right)$ and $\mathrm{F}$-values for the

2 variables net ecosystem production (NEP), ecosystem respiration (ER), and gross

3 ecosystem production (GEP). Means and F-values are reported for one-way ANOVAs

4 performed to compare data from Taylor Slough (TS) during the dry and wet seasons

5 individually with seasonally-pooled data from Shark River Slough (SRS). An asterisk

6 indicates that the TS data for a given variable were significantly different from data from

$7 \quad$ SRS $(\mathrm{p}<0.001)$.

8

TS Dry Season

TS Wet Season

$\underline{\text { SRS }}$

\begin{tabular}{cccccc} 
Variable & Mean $\pm \mathbf{S E}$ & F-value & Mean $\pm \mathbf{S E}$ & F-value & Mean $\pm \mathbf{S E}$ \\
\hline NEP & $2.49 \pm 0.27$ & 1.12 & $0.82 \pm 0.26$ & $27.78^{*}$ & $2.92 \pm 0.28$ \\
ER & $-2.53 \pm 0.19$ & $181.14^{*}$ & $-0.97 \pm 0.09$ & $17.03^{*}$ & $-0.55 \pm 0.09$ \\
GEP & $5.11 \pm 0.33$ & $14.40^{*}$ & $1.79 \pm 0.24$ & $12.69^{*}$ & $3.35 \pm 0.31$
\end{tabular}

9

10 
1 Table 3. Results from multiple regression analyses in which full models for NEP and GEP

2 included the predictor variables water depth relative to the soil surface, air temperature

3 ( $\mathrm{T}_{\text {air }}$ ), vapor pressure deficit (D), and photosynthetically active radiation (PAR). The PAR

4 term was excluded from the full ER models. Missing values indicate that a given predictor

5 variable was not included in the final model. An asterisk next to a predictor variable's

6 coefficient indicates significance at $\mathrm{p}<0.10$.

7

\begin{tabular}{|c|c|c|c|c|c|c|}
\hline & \multicolumn{3}{|c|}{ Taylor Slough (TS) } & \multicolumn{3}{|c|}{ Shark River Slough (SRS) } \\
\hline & NEP & ER & GEP & NEP & ER & GEP \\
\hline Intercept & 5.68 & -0.17 & 4.83 & 2.55 & 1.13 & 0.29 \\
\hline Water depth & -- & 1.30 & $-2.13 *$ & -- & -- & -- \\
\hline $\mathrm{T}_{\text {air }}$ & $-0.37^{*}$ & -- & -0.27 & 0.12 & $-0.10^{*}$ & $0.12^{*}$ \\
\hline $\mathrm{D}$ & $3.56^{*}$ & $-0.81 *$ & 3.31 & -- & $0.80^{*}$ & -- \\
\hline PAR & -- & NA & -- & -0.002 & NA & -- \\
\hline F-statistic & 3.29 & 11.63 & 9.03 & 2.42 & 7.56 & 5.57 \\
\hline Tolerance & 0.63 & 0.32 & 0.27 & 0.59 & 0.32 & 0.59 \\
\hline $\mathrm{R}^{2}$ adj & 0.26 & 0.62 & 0.65 & 0.24 & 0.59 & 0.34 \\
\hline$p$-value & 0.0761 & 0.0002 & 0.0034 & 0.1594 & 0.0178 & 0.0460 \\
\hline AIC & 8.13 & -9.76 & 8.04 & -0.24 & -19.54 & 1.57 \\
\hline
\end{tabular}




\section{Figure Legends}

2 Figure 1. Map showing the location of the study sites Taylor Slough (TS) and Shark River

3 Slough (SRS) within Everglades National Park.

4 Figure 2. Micrometeorological data from the short-hydroperiod Taylor Slough (TS) and

5 long-hydroperiod Shark River Slough (SRS) sites. Shown are water level data relative to

6 the soil surface with site specific wet seasons indicated by horizontal bars (A), air

7 temperature $\left(\mathrm{T}_{\text {air }},{ }^{\circ} \mathrm{C}, \mathrm{B}\right)$, vapor pressure deficit $(\mathrm{D}, \mathrm{kPa}, \mathrm{B})$, and daytime maximum

8 photosynthetically active radiation $\left(\mathrm{PAR}_{\max }, \mathrm{mol} \mathrm{m}^{-2} \mathrm{~s}^{-1}, \mathrm{D}\right)$. All data are presented as 7-day

9 running means so that seasonal patterns rather than day-to-day variation can be readily

10 observed. Note that micrometeorological measurements did not begin until early July 2008

11 at SRS.

12 Figure 3. Means \pm one $\mathrm{SE}$ for $\mathrm{CO}_{2}$ exchange rates $\left(\mu \mathrm{mol} \mathrm{CO} \mathrm{CO}^{-2} \mathrm{~s}^{-1}\right)$ measured at the short-

13 hydroperiod Taylor Slough (TS) site. Shown are values for net ecosystem production (NEP,

14 A), ecosystem respiration (ER, B), and gross ecosystem production (GEP, C) for both

15 control and periphyton removal treatments. Dry and wet seasons are indicated by white

16 and grey shading, respectively.

17 Figure 4. Means \pm one $\mathrm{SE}$ for $\mathrm{CO}_{2}$ exchange rates $\left(\mu \mathrm{mol} \mathrm{CO}_{2} \mathrm{~m}^{-2} \mathrm{~s}^{-1}\right)$ measured at the long-

18 hydroperiod Shark River Slough (SRS) site. Shown are values for net ecosystem production

19 (NEP, A), ecosystem respiration (ER, B), and gross ecosystem production (GEP, C) for both

20 control and macrophyte removal treatments. Dry and wet seasons are indicated by white

21 and grey shading, respectively. 


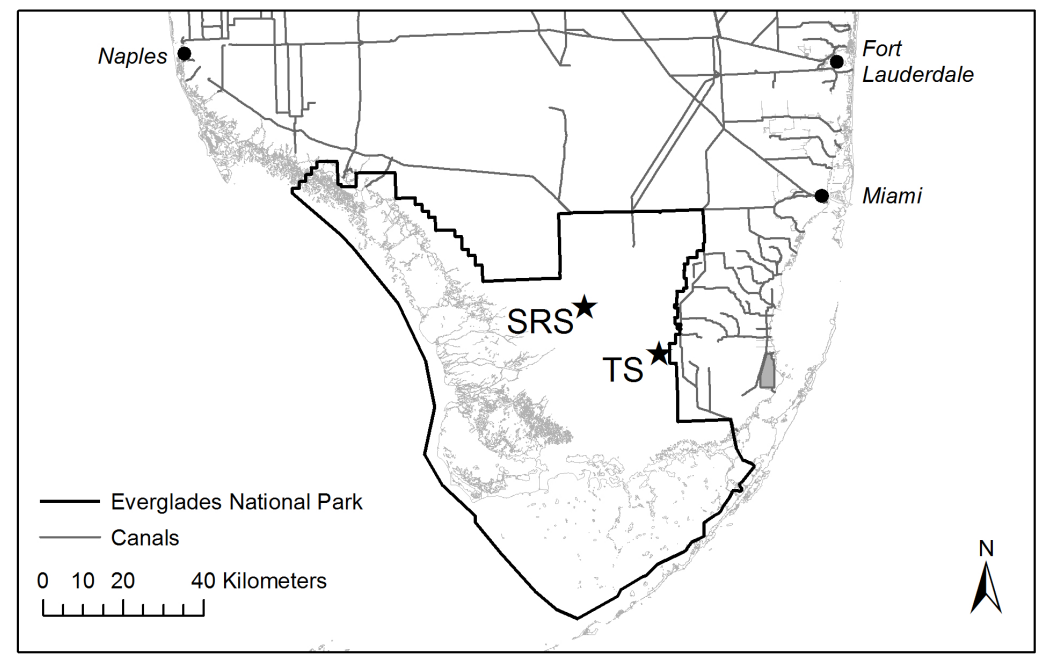

Fig. 1 


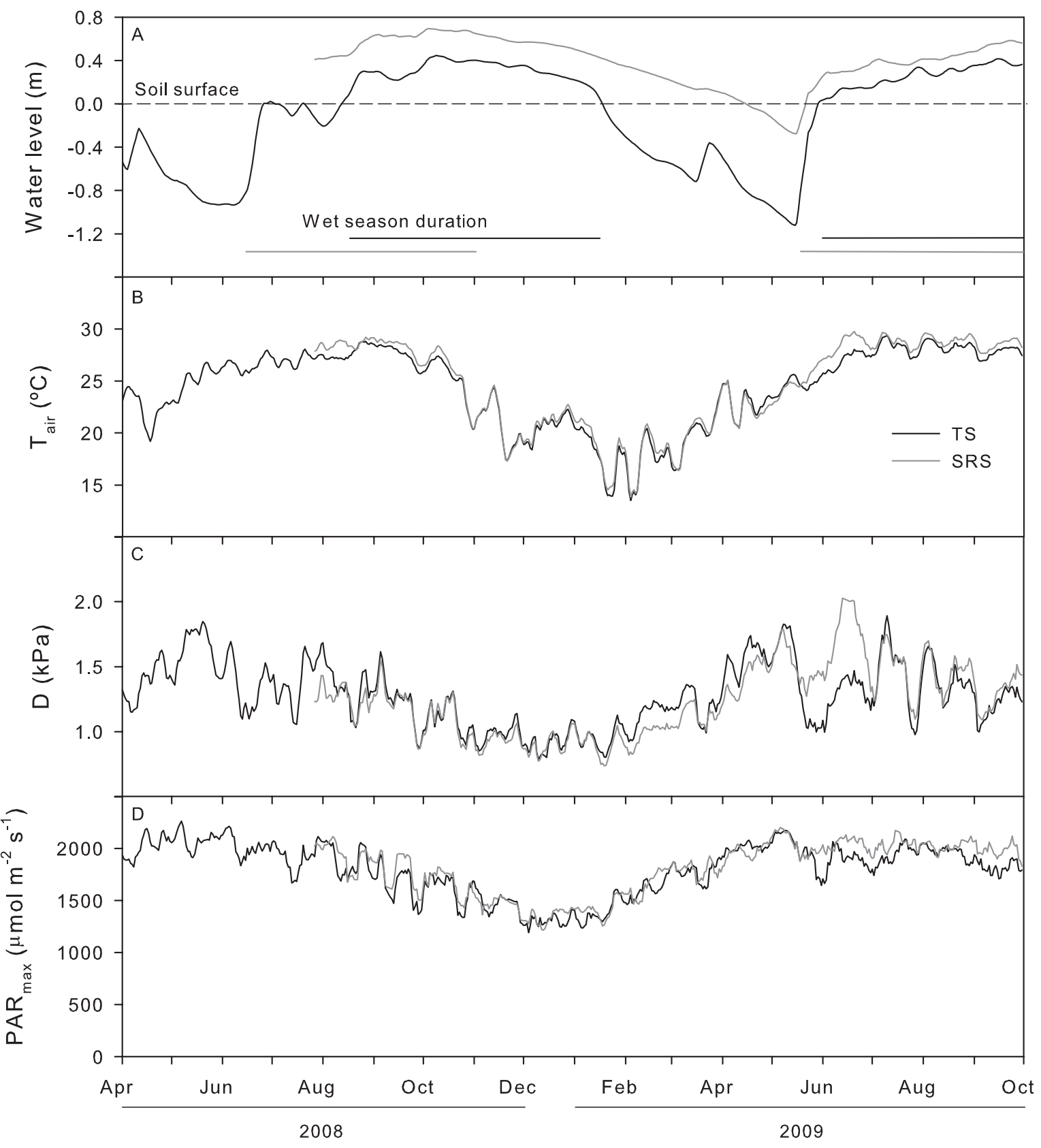

2

3

4

5 Fig. 2 


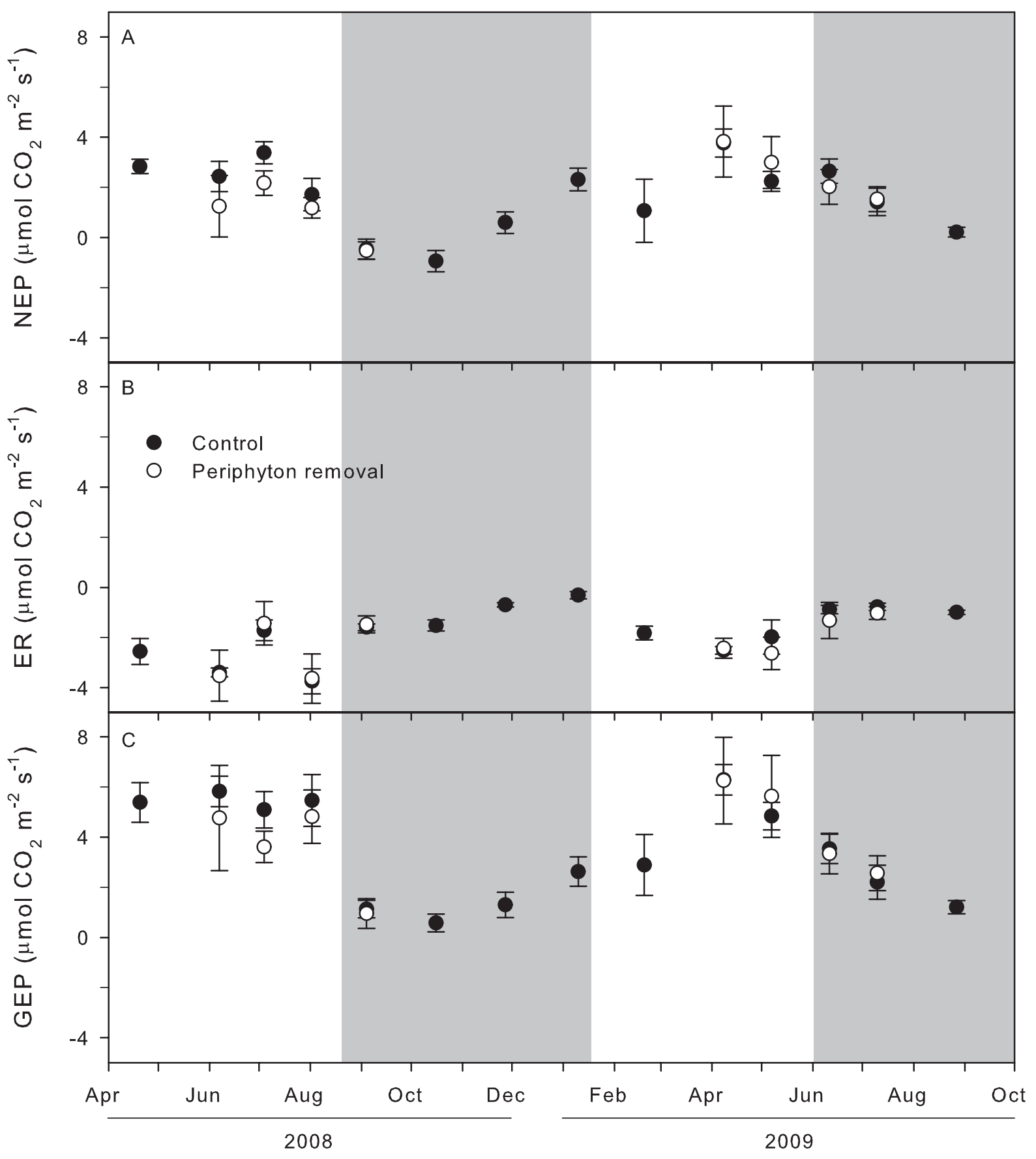

2

3

$4 \quad$ Fig. 3 


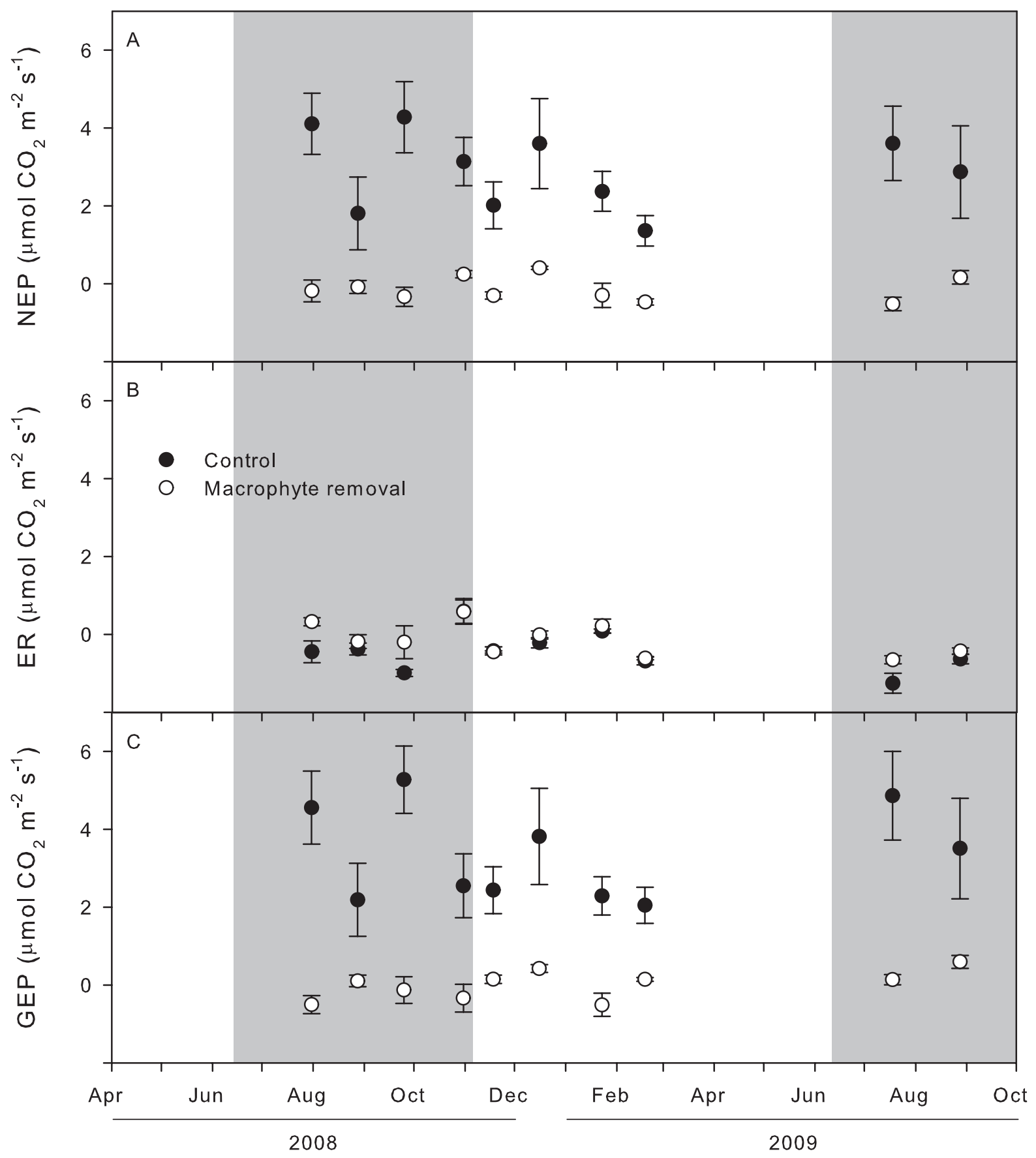

2

$4 \quad$ Fig. 4 